Information for citation:

Krasnova T. V., Alekseeva E. V. Ottsy I deti: problem priobreteniya roditel'skikh prav muzhchinami (na primere zakonodatel'stva Rossii) [Fathers and Sons: Problems of Acquiring Parental Rights by Men (a Case Study of the Russian Legislation)]. Vestnik Permskogo Universiteta. Juridicheskie Nauki - Perm University Herald. Juridical Sciences. 2016. Issue 34. Pp. 426-439. (In Russ.). DOI: 10.17072/1995-4190-2016-34-426-439.

UDC 347.634 .1

DOI: 10.17072/1995-4190-2016-34-426-439

\title{
FATHERS AND SONS: PROBLEMS OF ACQUIRING PARENTAL RIGHTS BY MEN (A CASE STUDY OF THE RUSSIAN LEGISLATION)
}

\section{T. V. Krasnova}

Tyumen State University

6, Volodarskogo st., Tyumen, 625000, Russia

ORCID: 0000-0002-3375-7443

ResearcherID: S-5442-2016

Articles in DB «Scopus» / «Web of Science»: DOI: $10.17072 / 1995-4190-2016-1-60-67$

e-mail: krasnova-tv@yandex.ru

\section{E. V. Alekseeva}

Tyumen State University

6, Volodarskogo st., Tyumen, 625000, Russia

ORCID: 0000-0002-4414-1409

ResearcherID: O-3326-2016

e-mail: alekseyevaev@inbox.ru

Introduction: in the article, the importance and specific features of acquiring parental rights by men are analyzed. The study of these issues does not only form scientific fundamentals to improve family law legislation but also shows potentialities of the "dialogue of generations" through the fixation of family values in a legal norm. Purpose: to develop well-grounded scientific recommendations and proposals essential for the improvement of family law in Russia and foreign countries. Methods: methodological framework of the research is based on a set of general scientific methods (analysis and synthesis, abstraction and concretization) and specific scientific methods (juridical dogmatic method, method of the legal norm interpretation). Results: the existing legal regulations on proving a child's descent from his/her farther imply many problems of scientific and applied nature. This results in infringing children's interests and fathers' parental rights. Cases of fictitious paternity establishment, for receiving a temporary residence permit in Russia, are getting widespread. New aspects of disputing paternity are revealed. The development of modern technologies in the reproductive sphere creates legal vacuum in the issues of establishing a child's descent from a father. Conclusions: the legislative importance of a state registration of paternity should be reconsidered. A child's birth should be accepted as a fact leading to the start of parental legal relations. Norms covering the issues of establishing the paternity of a person who is not married to a child's mother should be changed. The liability of a biological father should be strengthened and his interests should be protected. The possibility of voluntary recognition of paternity by people who evade the procedure of adoption should be excluded. It is necessary to amend the legal field with a procedure of declaring an act of fictitious paternity establishment to be invalid, with the compensation for moral damage to a child. The changes proposed are aimed at strengthening the social role of the father and overcoming the family crisis.

Keywords: parental rights; parental duties; parental legal relation; rights of children; child protection; establishment of paternity; presumption of paternity; registration of birth; family law legislation; family

(C) Krasnova T. V., Alekseeva E. V., 2016 


\section{Information on Russian}

\section{ОТЦЫ И ДЕТИ: ПРОБЛЕМЫ ПРИОБРЕТЕНИЯ РОДИТЕЛЬСКИХ ПРАВ МУЖЧИНАМИ (НА ПРИМЕРЕ ЗАКОНОДАТЕЛЬСТВА РОССИИ)}

\section{Т. В. Краснова}

Кандидат юридических наук, доцент, доцент кафедры гражданского права и процесса

Тюменский государственный университет

625000, Россия, г. Тюмень, ул. Володарского, 6

ORCID: 0000-0002-3375-7443

ResearcherID: S-5442-2016

Статьи в БД «Scopus» / «Web of Science»:

DOI: $10.17072 / 1995-4190-2016-1-60-67$

e-mail: krasnova-tv@yandex.ru

\section{Е. В. Алексеева}

Кандидат юридических наук, доцент кафедры теории государства и права и международного права Тюменский государственный университет

625000, Россия, г. Тюмень, ул. Володарского, 6

ORCID: 0000-0002-4414-1409

ResearcherID: O-3326-2016

e-mail: alekseyevaev@inbox.ru

Введение: в статье анализируются значение и особенности приобретения родительских прав мужчинами. Исследование этих вопросов не только формирует научную основу совершенствования семейного законодательства, но и показывает возможности «диалога поколений» через закрепление семейных иенностей в правовой норме. Цель: выработать научно обоснованные рекомендации и предложения, имеющие значение для развития семейного законодательства России и зарубежных стран. Методы: общенаучные методы: анализ и синтез, абстрагирование и конкретизация. Частнонаучные методы: юридико-догматический и метод толкования правовых норм. Результаты: существующие правовые положения об установлении происхождения ребенка от отияа характеризуются наличием множества проблем научного и практического характера. Это приводит к нарушению интересов детей и родительских прав отцов. Получают распространение случаи фиктивного признания отцовства для получения разрешения на временное пребывание в России. Выявляются новые аспекты проблемы уклонения от установления отцовства. Развитие современных технологий в сфере репродукции человека образует особую область правового вакуума в вопросах установления происхождения детей от отия. Выводы: правообразующее значение государственного удостоверения отиовства в России должно быть переосмыслено. Фактом, влекущим возникновение родительского правоотночения, долюсно быть признано рождение ребенка. Нуждаются в изменении нормы об установлении отцовства в отношении внебрачных детей. Следует усилить ответственность биологического отияа и обеспечить зашиту его интересов. При этом необходимо исключить возможность добровольного признания отиовства лицами, уклоняюшимися от процедуры усыновления. Требуется введение в правовое поле процедуры признания недействительным акта фиктивного установления отцовства с компенсацией морального вреда ребенку. Предложенные изменения направлены на укрепление сочиальной роли отца и преодоление кризиса семьи.

Ключевые слова: родительские права; родительские обязанности; родительское правоотношение; права детей; защита детей; установление отцовства; презумпция отцовства; регистрация рождения; семейное законодательство; семья 


\section{Introduction}

Thanks to the achievements of the world literature, every modern person has the opportunity to consider different edges of the relationships between the generations. One of the most essential aspects for discussion is the social importance of the fatherhood. It is more often that the fatherhood category is researched in the context of conservation of cultural traditions, which affects any society regardless of its economic welfare. There are historical and philosophical researches proving that the Romans' victory over the Greeks "was almost directly connected with their fatherhood cult" [4, p. 7]. As for the legal aspects of the relations between fathers and sons, they are also an important component of the dialogue of generations. However, from our point of view, they are given insufficient attention. Scientific publications are usually devoted to the problems of exercising the parental rights of the father and the mother associated with the marriage termination and the establishment of the place of the child's residence. In this context, the circumstances of the parents' equality principle realization are being researched. There is no scientists' attention given to the sphere of relations where the inequality of parents is vividly expressed and defined by the physiological features. The question is the issues of establishment of the children's descent from the parents. A child's descent from his mother, in the majority of cases, is obvious. The difficulties appear in the establishment of paternity, resulting in legal problems and conflicts of laws. In family law legislation of Russia, in a definite historical period (1918-1926) there was even a possibility for more than one father to be acknowledged simultaneously. This regulation was enshrined in the Code of Laws on the Acts of Civil Status, Marriage, Family and Guardianship Law of 1918. Article 144 of the document said: "When studying the case, should the court discover that a person indicated in the mother's application as the father of the child, although was in sexual relationship with the mother of the child at the moment of conception but also with other persons, the court takes a decision to involve all the latter as the defendants and imposes a duty on them to share the expenses associated with the pregnancy, birth and maintaining the child".

We think that the specific features of the parental rights acquisition by men should be adequately

\footnotetext{
${ }^{1}$ Code of Laws on the Acts of Civil Status, Marriage, Family and Guardianship Law. Collection of Statues of the RSFSR. 1918. No. 76-77. Art. 818. (repealed).
}

evaluated by researchers in order to improve their modern legal regulation, which is important since these aspects are fundamental for the parental legal relations and legally provide for equal responsibility of the parents for their child.

The history of the Russian family law development vividly underlines the importance of the legal issues of the paternity establishment, their influence on the formation of the image of the father in its perception by the society, and its interrelation with the modern crisis of the institution of the family. For example, sociologists and philosophers report on the weakening of the father's social role in modern Russia. Speaking about fathers, scientists use such a characteristic as "parental incompetence" [2, p. 15]. Legal experts urge to protect interests of fathers and to strengthen the father's position in the family using the legal methods [1]. In modern vocabulary, the "biological father" notion is differentiated, having a negative emotional connotation and referring to a man who neglects his function of upbringing and protection. The situation as it has developed causes bewilderment among people who know the historic past of the patriarchal Russia, which was characterized with a strong power of the father in the family. We find the explanations for this situation in the norms of the Soviet family legislation. In particular, in Decree by the Presidium of the Supreme Soviet of the USSR dd July 8, 1944 "On Reinforcing the State Support for Pregnant Women, Mothers with Many Children and Single Mothers, on Improving the Protection of the Motherhood and the Childhood, on the Establishment of the Honorary Title of the "MotherHeroine", on the Establishing Order "Mother's Glory" and Medal "Medal of Motherhood" (hereinafter referred to as the Decree) $)^{2}$. This Decree prohibited establishing paternity for children of unwed parents, which actually put fathers aside upbringing and maintaining their children. The prominent Soviet scientists of that period researching the problems of family relations warned that this rule would form a sense of irresponsibility of parents for the fate of their child. According to A. I. Pergament, who was among those scientists, the Decree contained contradictions between the law and morality and could not contribute "to the strengthening of the family and to developing proper moral qualities of a person as well as a proper attitude to performing the family obligations" [6, p. 72]. However, "blank certificates of

\footnotetext{
${ }^{2}$ Decree of the Presidium of the Supreme Soviet of the USSR of July 8, 1944. Gazette of the Supreme Soviet of the USSR. 1944. No. 37. (repealed).
} 
birth" - when the "father" space was marked with a strikethrough for a child of unwed parents - existed in Russia until 1969. Thus, during a period of more than 20 years a type of the fatherhood was forming when the father had no responsibility for his child. This historical experience is the key to be used for approaching the future of Russian family law and that can also be useful for developing legal norms of other nations.

In the existing family law of Russia, the role of paternity establishment by the state via the registration of paternity in the executive bodies of the state authority of the Russian Federation territorial entities - civil registry offices (hereinafter referred to as registry offices) - is very important. In fact, paternity establishment is limited to making entries into the child's birth record. In accordance with Article 47 of the Russian Federation Family Code (hereinafter referred to as the RF FC) ${ }^{1}$ this record is a mandatory condition for starting the family legal relations between the father and the child. We deem it necessary to review the existing order of acquiring parental rights by men. On the one hand, there are no parental rights without the registration of a person as the father and nobody can make him to perform his parental duties (although we consider it disputable from the legal and moral perspectives). On the other hand, the existing order of establishing paternity allows for registering as the father of the child a person who is not in fact his father. It results in a number of problems in the law enforcement practice - starting with the classical problem of disputing the entry about the father and finishing with the problems not known earlier in the law enforcement practice, e. g. fictitious paternity establishment for receiving a temporary residence permit in the country by migrants under the pretense of the so-called "family reunification".

Social processes, the development of science and medical technologies has led to the newest aspects in the issues concerning establishing a child's descent from his father. In particular, these affect the relations associated with the application of the assisted reproductive technologies (hereinafter ART), including post mortem procreation. Due to the physiological factors, post mortem extracting of gametes is only possible from men (as specialists specify, there could be only ovarian structure ex-

\footnotetext{
${ }^{1}$ Family Code of the Russian Federation: Federal Law of December 29, 1995, No. 223-FZ. RF Collection of Laws. 1996. No. 1. Art. 16.
}

tracted from women that can be later used for cultivating an oocyte $[9$, p. 33]). The question of establishing paternity and other ethical questions arising in this context are not agreed upon in the world science and are not being widely discussed by Russian scientists.

The negative consequences of the mentioned legal conflicts influence, first of all, interests of children, fathers and mothers. However, they also influence interests of all the family members because the parental legal relation can only be isolated in theory, while in real life all the relations are interdependent. Ultimately, it is possible to speak about the imbalance of the whole society which is being built based on the destabilized and contradictory legal conditions of the family existence.

Taking the abovementioned into consideration, the purpose of this article is to analyse the problems of the legal regulation of the relations concerning the establishment of the legal connection between a child and his father that are meaningful for improving the legislation of Russia and foreign countries.

\section{Meaning of the Public Registration of Paternity and its Grounds}

According to the current family legislation, legal relations between a parent and a child start from the moment when the child's birth is registered and data about the mother and the father are recorded. It is obvious that between the moment of the child's birth and the moment of its registration and making entries about the father and the mother, a significant period of time can pass. The law allows one month for reporting a child's birth (Cl. 6 Art. 16 of the Federal Law No 143-FZ dd November 15, 1997 "On Acts of Civil Status" (hereinafter referred to as the Civil Status Acts Law) $)^{2}$. Moreover, Article 21 of the Civil Status Acts Law provides for a possibility to report the birth of a child who is one year old and older (until the child is 18 , after which he can report his birth personally). There are no juridical consequences for parents (except for minor procedural changes) for missing the term defined for the child's birth registration. Therefore, during this "gap" period of time, there is no legal relation between the child and the parents. Moreover, with no state registration of the child's birth, there is no

\footnotetext{
${ }^{2}$ On Acts of Civil Status: Federal Law of November 15, 1997, No. 143-FZ. RF Collection of Laws. 1997. No. 47. Art. 5340.
} 
child as a legal subject. Although Russia has acknowledged that the rights and freedoms belong to a person from the moment of his birth, the person's interests are not subject to the legal protection in case his birth has not been registered by the state. Thus, we think that the Russian legislation has come to a situation when "the tail wags the dog", i.e. the public registration of birth, which is in essence of an accessory nature, is given the meaning of the investitive fact. For this reason, there are proposals in scientific literature to legally define the moment of the parental rights and duties emergence. It is proposed to consider the fact of a woman's pregnancy verification to be this moment. In opinion of A. K. Polyanina, "in the intrauterine development period, a child could be granted with a right to being cared of by his parents, to protection of his interests and to his all-round development. At the same time, the parents are answerable for the upbringing and development of their children including those in the mother's womb" [7, p. 10]. In accordance with the Convention on the Rights of the Child of the United Nations Organization, every child has the inherent right to survival and development (Article 6) ${ }^{1}$. As A. M. Rabets notices, "the survival and healthy development of the child should be provided yet during the intrauterine period" [8, p. 252]. However, the differences existing in the culture of the multinational Russian society do not allow for the development of a unified opinion about the possibility in principle, and about the term of the child's intrauterine period for acknowledging his independent legal status. The differences between the states in their legal systems, in their legislations about the induced termination of pregnancy (abortions) are the barrier for the international acknowledgement of a child as a legal subject before his birth. As a result, the opportunity for providing guarantees for the protection of life since the moment of conception remains a disputable issue [14, sec. 133-136], and it is the child's birth which is considered to be the juridical fact for his rights to arise. It is important that in accordance with Article 7 of the Convention on the Rights of the Child of the United Nations Organization, the child shall be registered immediately after his actual birth. In accordance with this norm, from birth a child shall have the right to a name and the right to

\footnotetext{
${ }^{1}$ United Nations Convention on the Rights of the Child 1989. Gazette of the Congress of People's Deputies of the USSR and the Supreme Soviet of the USSR, dd November 7, 1990, No. 45, Art. 955.
}

acquire a nationality, and, as far as possible, to know his or her parents and be cared of by them. It should be mentioned that long before the Convention on the Rights of the Child was developed, the same position had been justified by Russian scientists [6, p. 67], but it has never been reflected in the legislation and the practice of its application.

Therefore, the order stipulated in Clause 6 of Article 16 of the Civil Status Acts Law does not comply with the norms of the international law. We deem it necessary to reconsider the meaning of the state registration of the child's birth. It is to be regarded as the parents' duty that arises with the child's birth. The norms of family law legislation on the grounds for the parental relations to arise should be revised. In this respect, noteworthy is the experience of Tatarstan, where the birth registration offices are organized in some of maternity hospitals of the Republic. Such novelties will strengthen the legal protection of the child's interests in Russia; will remove the situations of the legal uncertainty when parents fail to report the child's birth in the Civil Acts Registration Agency and therefore juridically have no parental duties; will guarantee legal protection for the persons who failed to report the child's birth in the Civil Acts Registration Agency due to a reasonable excuse. Moreover, they will serve as a basis for the legislation changes proposed in this article for strengthening the responsibilities of fathers of children born to unwed parents and for providing the equality of parents. Observance of this principle in the existing family legislation is disputable because the rights of the father and the mother arise not simultaneously in many cases.

Indeed, the grounds and the moment of gaining the parental rights by the mother do not change depending on her marital status. The order of gaining the parental rights by the father depends on whether he is married or not married to the child's mother. It is important that this circumstance determines the moment of the father's parental rights emergence. The parental rights of both the father and the mother can arise simultaneously at the moment of the child's birth registration in case the entry about the father is made based on the Certificate of Marriage with the mother of the child (presumption of paternity).

The classical presumption that the husband of the child's mother is considered to be the father of the child, is in effect in legislations of most states. The effect of this presumption in Russia covers the cases when the child is born 300 days after the marriage dissolution or the annulment of the marriage 
or its termination due to the death of the husband of the child's mother (Cl. 2 Art. 48 of the RF Family Code). As a rule, the presumption of paternity is positively characterized in scientific literature. Its role is emphasized in simplifying the child's birth registration procedure and in the protection of his interests. However, there are some opposing views among scholars criticizing application of the presumption of paternity. Basically, they are explained by the purpose of protecting the interests of the mother's husband who is not a "biological" father of her child, e.g. when the child is knowingly conceived as a result of the adultery or when the married spouses live separately not having officially terminated their marriage. For denoting such casuses that require destroying the presumption in the court proceedings, it is proposed to use a term "bound juridical paternity" [18, p. 90].

With the account for such situations, N. A. Matveeva proposes to legislatively formalize the opportunity for the Russian citizens to have a simpler variant of solving this issue than the existing opportunity provided for by the RF FC to contest paternity in court. For example, the same is provided in Article 51 of the Code of Marriage and Family of the Republic of Belarus. It says that "the child's descent from a father who is not married to the child's mother, in case the mother is married to another person, is established based on a joint application of the child's father and mother about the registration of the paternity establishment and the mother's report that her husband is not the child's father submitted to the offices registering acts of the civil status or based on the court's decision about the paternity establishment" [5, p. 41].

The parental rights of the persons who are not married to each other, can also arise simultaneously. However, only on the condition that the joint application is submitted simultaneously with the child's birth registration. Otherwise, when registering the child's birth, the mother acquires the legal status of a parent but the father does not. The record about the father can be made at the request of a single mother but this does not result in the legal relations with the recorded person $(\mathrm{Cl} .3$ Art. 17 of the Civil Status Acts Law). Thereby, there is an actual relief of the parental duties for the man. At the mother's will, there can be no entries about the father at all. With this, according to the Russian Federation national statistics, the number of children born to unmarried parents grows. Every third child and since $2010-$ every fourth child is the child of unwed parents ${ }^{1}$.

\footnotetext{
${ }^{1}$ Concept of the State Family Policy of the Russian Federa-
} tion for the Period up to 2025 (public project): Part 1 / Pre-
After the child's birth is registered, paternity can be established at any time, even after the child comes to the age of majority, on the condition of the child's consent (Cl. 4 Art. 48 of the RF FC). Voluntary establishment of paternity can be performed at any time with the joint (with the child's mother) application submitted to the Civil Acts Registration Agency; in case the mother died, is legally incapable or deprived of parenthood, also in case there is no opportunity to know the place of her residence, paternity establishment is performed with the application of the father, with the consent of the Guardianship and Trusteeship Body, and in case there is no consent - through a court procedure (Pt. 2 Cl. 3 Art. 48 of the RF FC).

In case the mother disagrees to establish paternity or the child's biological father, the father's parental duties can be established through a court procedure (Art. 48 of the RF FC). By all appearances, this is also the only opportunity for persons who are willing to establish their paternity but are legally incapable in accordance with the court decision (the right of the guardian to apply to the Civil Acts Registration Agency on behalf of an incapable person is disputable due to the personal character of the parental legal relation). Paternity of a dead person can also be established in court in case it is possible to prove that he acknowledged his fatherhood when alive. In this case, the meaning of the public paternity establishment is limited to discovering the inheritance link. It is notable that in the family law theory, the practicability of paternity establishment by the court is disputed due to the impossibility to involve the person into the upbringing of his child and into the communication with him. For protecting the financial interests of the child in such cases, scientists propose to legitimize the opportunity to exact alimony from the biological father with no gaining the parental rights by him [3, p. 23].

An important aspect of establishing paternity is awarding the child with the patronymic name. In accordance with the general requirement of Article 58 of the RF FC and Clause 4 of Article 18 of the Civil Status Acts Law, the child's patronymic name shall be awarded according to the father's name. The patronymic name should originate from the father's name even in cases when the paternity was not established and the entry about the father was made as directed by the mother. The patronymic

pared by E. B. Mizulina. Available at: http://www.komitet26.km.duma. gov.ru/site.xp/050049124053056052.html (accessed 06.10.2016). 
name is registered as directed by the mother only in case the single mother's will is not to introduce the father's information into the official entry on the birth of the child. Let us emphasize that refusal to award a patronymic name to a child, in accordance with the general rule, is not admissible. As per Article 19 of the Russian Federation Civil Code (hereinafter referred to as the RF $\mathrm{CC})^{1}$, a patronymic name is a mandatory element of the name, which in Russia includes a name itself, a patronymic name and a surname. Therefore, the refusal to give a patronymic name to a child will be evaluated as the infringement of the child's right to have a name. As an example can be given a court decision on the dispute between the Civil Acts Registration Agency of Moscow and the parents who did not want to give a patronymic name to their child and wanted the child to be named with abbreviation "BOCh rVF 260602" (meaning "biological object human from the family Voronins-Frolovs, born on June 26, 2002"). The court's decision mentioned the fact of the infringement of the child's right to have a name as deemed by Article 19 of the RF $\mathrm{CC}^{2}$. According to the mass media, the birth of this child is still not registered because the parents continue to stand for their decision to call the child in the manner they want. It is only a national tradition or a regulation of the Russian Federation constituent entity legitimizing the corresponding practice that can make an exception from the general rule of giving a patronymic name. This can allow for no patronymic name or for adding definite words to the name of the father. For example, according to Clause 3 of Article 49 of the Family Code of the Republic of Tatarstan, word "uly" is added to the name of the father of the boy, and word "kyzy" is added to the name of the father of the girl. ${ }^{3}$.

Thus, in accordance with the existing legislation of the Russian Federation, the public establishment of paternity is a mandatory condition for acquiring the rights and duties of the father, it determines the order of the realization of the child's right to the name. In our opinion, the meaning of this juridical action in modern Russian law requires revision. It is the child's birth that should be

\footnotetext{
${ }^{1}$ Civil Code of the Russian Federation (Part 1): Federal Law of November 30, 1994, No. 51-FZ. RF Collection of Laws. 1994. No. 32. Art. 3301.

${ }^{2}$ Web source. Available at: http://forum.garant.ru/?read,7,1079 334 (accessed 06.10.2016).

${ }^{3}$ Family Code of the Republic of Tatarstan of January 13, 2009, No. 4-ZRT. Republic of Tatarstan. 2009. No. 8.
}

acknowledged as the only necessary and sufficient ground for acquiring the parental rights.

\section{The Current Issues of Practice: Fictitious Paternity Establishment and Evasion of Paternity Establishment}

As the analysis of practice has shown, most problems of the legal regulation refer to the sphere of realization of norms concerning voluntary paternity establishment.

A relatively new problem for the Russian lawenforcement practice is the one of falsity when establishing paternity. In family legal relations, such a negative phenomenon as the fictitious state is not seldom to occur. There were fictitious marriages known earlier effected mainly for improving the living conditions. For the same purpose, fictitious dissolution of the marriage and fictitious division of property took place, which allowed former spouses to formally terminate the community of goods and participate in different national programs of improving the living conditions. However, there is no definition of the fictitious nature in the RF FC. We propose to define the fictitious nature as performing a legal action with no purpose of achieving the purpose assumed. De lege lata the purpose of establishing paternity should be getting the juridical authority for upbringing and maintaining one's child. Correspondingly, fictitious paternity establishment is a voluntary acknowledgement of paternity in respect of a child having no biological connection with the man, with no purpose of this child's upbringing and maintaining. It got widespread after Russia ratified the European Social Charter ${ }^{4}$. In compliance with the international norm, Federal Law No 115-FZ dd July 25, 2002 "On the Legal Status of Foreign Citizens in the Russian Federation" in its Clause 6.2 provided for an opportunity to receive a temporary residence permit in Russia for a migrant having a child with the Russian Federation citizenship outside the corresponding quota. According to reports from the Russian migrant services, since the quotas are limited in number, people willing to get a temporary residence permit have learnt to use the opportunities of the RF family legislation to circumvent the restrictions. The mother of the child gets a

\footnotetext{
${ }^{4}$ European Social Charter. Bulletin of International Agreements. 2010. No. 4. P. 17-67.

${ }^{5}$ On the Legal Status of the Foreign Citizens in the Russian Federation: Federal Law of July 25, 2002, No. 115-FZ. RF Collection of Laws. July 29, 2002. No. 30. Art. 3032.
} 
reward for her consent, so a special type of illegal "earnings" is developed.

When committing such a fictitious juridical action, the father himself falls into a legal "trap" of Clause 2 of Article 52 of the RF Family Code, according to which the paternity record cannot be annulled in the future at the initiative of the father, if at the moment of making this entry the person knew that he was actually not the father of the child. However, keeping the legal connection between the child and the person who is not his actual father and has no purpose to bring him up and maintain, as we see it, contradicts the interests of the child himself. Conversely, we consider disputing the paternity by the child's representative to be an insufficient way out. As far as the fictitious paternity establishment is the violation of law, a measure is required which could combine the opportunities for protecting the child's interests and the responsibility of the offender. For this purpose, we consider it necessary to introduce a special norm about the invalidity of fictitious paternity: "fictitious paternity is understood as voluntary acknowledgement of paternity by a person who is not biologically the father of a child of a single mother, with no purpose of maintaining the child and bringing him up". It is not by chance that this wording does not indicate the administrative order of paternity establishment. This can inspire the adventurous offenders to establish fictitious fatherhood through the court procedure by misusing their right to admitting the claim. The right to apply to the court with the claim to declare the paternity establishment act invalid should be given to the Prosecutor, to the bodies and organizations having obligations of protecting rights of the juveniles, and to the children's rights ombudsmen. Declaring paternity invalid should result not only in the annulment of the father's record but also in settling the claim for compensation for moral damage to the child. Within the framework of the same procedure, it is necessary to warn the mother of the child about the inadmissibility to misuse her parental rights, and to decide the issue of holding her administratively liable by paying a fine, the size of which should be determined in legislation on administrative offence. Besides compensating for the moral damage, the immigrant worker who fictitiously established his fatherhood should face all the consequences provided for by the migration legislation in connection with losing the legal grounds for temporary residence.
Noteworthy is that the problem of fictitious paternity is typical not only of Russia. For example, in the Constitutional Court of the Federal Republic of Germany, the legal evaluation was given to the facts of establishing fatherhood with respect to migrant children by citizens who are not biologically fathers of these children; the evaluation was also given to the question of the legitimacy of initiating genetic tests and fatherhood disputing by the authorized state bodies in these cases [16]. Due to the necessity to protect interests of the child, and for avoiding the situation when the child can lose his right to citizenship or residence permit, the court acknowledged the legal connection even in case of no family and social relations between the father de jure and the child ${ }^{1}$.

In practice, it is not uncommon that voluntary establishment of paternity for a child of a single mother is used by men (e.g., by a father-in-law) to avoid the complex procedure of adoption. At the same time, the child's interests could be hurt in case the person who has no right to be an adoptive parent as per Article 127 of the RF FC gets the right to bring the child up (e.g., a person who was earlier deprived of parenthood). Surely, such circumstances should be the reason for the annulment of the voluntary fatherhood establishment records. However, the RF FC does not forbid a person who is not the father of the child to establish paternity, moreover, it takes this circumstance into account in Clause 2 of Article 52 of the Russian Federation Family Code. Therefore, in this case, there are no violations of the legislation specific requirements on establishing fatherhood. The purpose of adoption and establishing paternity coincide, there are purposes of creating the appropriate legal consequences. Therefore, amending the paternity establishment sphere with the regulations on the fictitious nature will not be a sufficient measure. We propose to prohibit voluntary paternity establishment by a person who knows that he is not the father of the child. We think that only the adoption institution is meant for that. Thereby, there will appear legal grounds for declaring the voluntary paternity establishment act invalid in case it is proved that paternity was established by persons evading the procedure of adoption.

The practice of evading paternity establishment for the purpose of getting privileges and material

\footnotetext{
${ }^{1}$ BVerfG, Beschluss des Ersten Senats vom 17. Dezember 2013 - 1 BvL 6/10 - Rn. (1-116). Available at: http://www.bverfg. de/e/ls20131217_1bvl000610.html (accessed 06.10.2016).
} 
bonuses guaranteed to single mothers by the Russian state has been known for even longer period. "Single" mothers, children and their fathers often live together, actually forming a family. It is obvious that in these cases the misuse of rights to getting social benefits takes place. However, practice has revealed one more risk within the current legislation requiring discussion. A citizen I. contacted a law firm "Dela Semeinye" of the city of Tyumen requesting to assist him in protecting his parental rights. He explained that for several years he and his wife had lived together with their common under aged children not effecting a marriage and having not established his paternity. In May 2015, he had to leave for distant regions of the Extreme North for a long-term business trip. On his return home, he was informed that his wife had died and his children had been taken for adoption due to the loss of the parental care. The state bodies and officials refused to give him the information about adoptive parents in accordance with the requirements of Article 139 of the RF FC about the inadmissibility to disclose the adoption details. In addition, citizen I. could give no evidence of his being the father of the adopted children.

In our opinion, it is obvious that the adoption must be annulled: presence of the biological father who is willing to honestly perform his parental duties, on the one hand; the children's interest in their father's upbringing and a short period of adoption, during which a strong affection for the adoptive parent could hardly appear, on the other hand. However, the legal barriers associated with the secret of adoption have not been overcome in the example given.

Thus, we make a conclusion that a new order of acquiring the parental rights by men with respect to their children born out of wedlock should be developed. The abovementioned regulations on the equality of parental rights of women and men allow for proposing a concept of the mandatory paternity establishment. There is no doubt that the mother's record is necessarily made when the child's birth is registered (except cases when the child has been lost and found). In that connection, it is irrelevant to speak about the infringement of somebody's rights by the requirement to obligatory establish paternity. It goes without saying that a special legal instrument should be developed for this. Introduction of the new order of establishing paternity should be aimed at both protection of children born out of wedlock and strengthening of fathers' legal posi- tions. As the famous Russian scientist L. I. Petrazhitskiy notes, the law has a constant and strong disciplinary influence onto the individual and the mass mind, reinforcing the socially desired practices and habits and liquidating elements of the opposite nature [11, p. 146]. For this reason, we think that the father's positions in the Russian society should be strengthened by reinforcing his parental responsibility. In particular, we propose to amend the existing Russian legislation on civil status acts with a norm that will allow a single mother to inform the civil act registration agency about who is the father of the child. It is necessary to oblige the civil act registration officials to inform the corresponding person about the fact of his being reported as the father of the child. For the observance of the balance of interests, a term should be given to the person indicated by the mother for disputing his fatherhood in court. Due to this procedure, the child's descent from his father will be established in all the cases of a child's birth. Thereby, the conditions for exercising and protecting the child's right to know his parents will be created to the fullest extent. Finally, such a legislative decision will eliminate the cases of the fathers' rights infringement described in this section.

\section{Specific Features of Paternity Establishment in Cases of Using Assisted Reproductive Technology}

The issues of assisted reproduction were first regulated in Russia in 1990. An amendment was made to Article 17 of the Marriage and Family Principles of the USSR and the Union Republics according to which a husband who gave his consent to applying the method of artificial fertilization of his wife with the help of a donor is recorded as the father of the child and shall not have the right to dispute the record ${ }^{1}$.

The literal interpretation of the norms of the existing family legislation results in conclusion that the application of the method mentioned is only allowed for the married people (Cl. 4 Art. 51 of the RF FC). Many scientists consider Article 51 to unreasonably restrict rights of single women. However, the idea of single men's participation in programs of surrogate maternity is, as a rule, not supported. As E. V. Stebleva notes, such a regulation

\footnotetext{
${ }^{1}$ On the Approval of the Fundamentals of Legislation of the USSR and the Union Republics on Marriage and Family: Law of the USSR of June 27, 1968 No. 2834-VII. Gazette of the Supreme Soviet of the USSR. 1968. No. 27. Art. 241.
} 
will contradict the purpose of surrogate maternity, which is to overcome infertility of a woman who cannot carry to term and give birth to a baby for medical reasons [10, p. 14]. Thus, a man can only participate in assisted reproduction as a husband or a donor.

No matter which kind of assisted reproduction programs is applied (artificial insemination, in vitro fertilization, etc.), a man's participation in procedures of assisted reproduction technologies is limited to the extraction of his biological material, without participation in further manipulations. In case the fertilization takes place with the use of a donor's genetic material, a man does not participate in medical manipulations at all. The interests of both the man and his wife totally depend on the honesty and professionalism of the staff of the medical organization providing assisted reproductive technology procedures. As practice shows, in such cases the interests of the man also depend on the honesty of his wife. In a medical center of Tyumen, during the procedure of in vitro fertilization, it occurred that a woman intentionally replaced the biological material of her husband with another material received earlier for these purposes. If the procedure had resulted in birth of a baby, a complex ethical and legal problem would have appeared - in accordance with the documents, the parental rights would have belonged to the husband who had agreed to applying the method of artificial fertilization of his wife. The fatherhood of the person whose biological material was actually used would have arise with no consent of his and with no legal arrangements. Finding the guilt of the woman would have decide nothing in the fate of the person born due to such a "mistake".

Such examples motivate for an attentive legislator's attitude toward the very procedure of applying in vitro fertilization, which has a lot of uncertainties at the moment. For example, in case several ovums were successfully fertilized outside a woman's body, a question will be discussed on how many of them should be transferred into the woman's body and what to do with the others. It is a well-known fact that ovums can either be frozen or destroyed. However, no single legislation act regulates the man's participation in solving this question.

In foreign practice, there were some resonant cases with claims of biological fathers who acted as non-anonymous donors of gametes used for fertilization by single mothers of homosexual couples (including cases of doing it independently, with no assistance from specialized medical centers). The biological fathers claimed for an opportunity to communicate with the children, for exercising their parental rights and for the identification of their legal status $[12,15]$. Equally, the contrary situations took place when the mother of the child who originally agreed to no obligations on the part of the non-anonymous donor, later initiated establishing of his fatherhood in court due to the changed life circumstances.

In the Russian Federation, such a type of donorship is admissible and is often chosen by single women. At the same time, the corresponding risks and conflicts of interests are not yet regulated by the legislation. It appears that a child born from a non-anonymous donor should have a guaranteed opportunity to receive information about his biological father, for example after he reaches the age of majority, regardless of the mother's will, or earlier - with her consent. It is important for the child's self-identification and will allow him to realize the right to know his parents (Art. 7 of the United Nations Convention on the Rights of the Child).

A non-anonymous donor can claim for the establishment of his fatherhood, including the cases when the child's mother does not give her consent, and Article 48 of the RF Family Code does not contain exceptions in respect of this situation. It is obvious that the right to know one's progeny is inextricably linked to the person's self-determination and refers to the natural personal rights in its essence [22, p. 64]. However, it is no less important that the claims of the biological father do not infringe the child's interests and do not lead to interference in the personal and family life.

One of the solutions to this problem in foreign practice is the acknowledgement of the legal force of the agreement between the man-donor and the woman-recipient that defines their mutual rights and duties in case the child is born. We think that this experience can be taken into consideration for improving the Russian legislation.

Another issue requiring special treatment is the one of post mortal fatherhood. This term means conceiving a child using gametes and also implantation of an embryo right before the death of the 
man or at any time after his death [20, p. 289]. It should be noted that in foreign legislation and practice the attitude to the possibility of applying assisted reproductive technology post mortem is quite debatable, ranging from the permission to use it to the absolute prohibition. When choosing the model of legal regulation, a special attention is given to the question of the child's welfare protection because it may happen that his being born without the dead father's will can negatively influence the development of his personality. Furthermore, the regulation on protecting the personal rights of the gamete donor is considered to have the dominant importance since it is directly associated with the donor's inherent rights and his self-perception in the issues of the continuation of his family line [23, pp. 27-29] and has psycho-emotional consequences for the children [20, p. 295].

In Russian legislation, these issues are not yet directly regulated. At the same time, conceiving of a child with the use of gametes of a dead man can take place in the following cases. Firstly, in case a man who joined an assisted reproduction program together with his wife dies after the phase of extracting his genetic material. If the consent for the use of his material and application of ART was given in advance, his will for the continuation of his family line is vivid and the fact of the child being conceived by this very person (biological fatherhood) is verifiable. However, the obstacle for his being recorded as the father of the child based on the presumption of paternity is the term that will exceed 300 days specified in the RF Family Code for the natural conceiving of a baby within marriage. Thus, we deem it useful to shift this deadline for the cases of parents' participation in an assisted reproduction program. This alteration can be made to Clause 2 of Article 48 of the Russian Federation Family Code as an amendment to the rules of applying the presumption of paternity of the mother's husband: "...Also, should the child be conceived and born after the death of the mother's husband who gave his consent to apply methods of assisted reproduction using his gametes".

It is also possible that material is used from a donor who died before ART application. As far as the gamete donor is usually anonymous, the child's birth after the donor's death has no legal consequences. Presumably, the information on whether the donor is alive at the moment of the manipulation is not verified, as a general rule. However, it is reasonable to legislatively provide for the oppor- tunity to check this information at the request of the woman who takes the decision about the use of the particular donor's material.

Secondly, if a man applies cryopreservation of his gametes, there should a question arise after his death about who is supposed to control usage of these gametes. In most states, the critically important circumstance is the direct will of the person who put the material for storage about the terms of storage, its purposes and the persons authorized. Sharing this approach, we consider it necessary to clarify the man's will at the phase of extracting the genetic material. For this, health care legislation should be amended with the corresponding requirement for the medical organizations accepting the material for storage. Taking into account the fact that the existing technologies allow for storage of genetic material without its deterioration over a long period of time, we think that soon a problem will arise concerning juridical limitation of the term for using the frozen gametes for conceiving a baby. The optimal term should be suggested as a result of discussions about the ethical aspects of the problem. For example, from our point of view, when conceiving a child, it is necessary to observe the natural periods of changing the generations, to avoid the situation when a child descends from persons who were never able to meet each other due to the limited term of the human life cycle.

Thirdly, post mortal reproduction takes place when genetic material is extracted after the pronouncement of death. Data about such a possibility was first published in 1980 [19, p. 512]. The first baby conceived with the help of this method was born in 1999 [21, p. 739]. In Russia, a post mortal ART program when biological material was received after the parent's death was successfully completed in 2003-2006 in Yekaterinburg [9, pp. 40-41]. Situations can also take place when material is extracted from a man in coma, in vegetable state, after the brain death and is later used for the reproduction purposes [13, p. 171].

In respect to the cases mentioned, an opinion seems to be just that intentions expressed in advance by the dead person concerning this situation should be the decisive point. However, the questions of post mortal gamete extraction from a man who did not manage to express his opinion, are also noteworthy. Some scientists propose to legally provide for this opportunity for a wide range of people - for all people of a child producing age who died in emergency circumstances [9, p. 41]. Still guided 
by the naturally legal character of relations between parents and children, we propose to judge from the will of the surviving spouse when solving this issue. The opportunity to use these gametes should be given to her on the condition that she will exclusively be recorded as the child's mother, but not to other relatives. The purpose of this assumption by the legislator will be protection of reproductive rights of the woman who was married to the dead, this also complies with the purposes of Article 8 of the European Convention for the Protection of Human Rights and Fundamental Freedoms ${ }^{1}$.

We believe that at the moment application of assisted reproductive technology methods should be regarded as the way to overcome sterility, with the course of nature being kept as much as possible. In our opinion, consciousness of people and the state of the modern legal systems are not ready for fantastic variants of the situation development when applying assisted technologies.

\section{Conclusion}

Thus, birth of a child is the circumstance necessary and sufficient for parental rights and duties to arise. Family legislation of Russia needs to be amended with a norm that provides for the acquisition of parental rights both by the child's mother and his father simultaneously at the moment when the child is born. With this, it is reasonable to directly state in the Russian Federation Family Code that the child's registration has a notifying character and is a duty of the parents. The new approach to understanding the meaning of paternity establishment should also be reflected in the RF Family Code. Its essence is not in gaining parental rights and duties but in providing for the best conditions for their protection. Taking into account the fact that the existing order of establishing paternity for a child born to unmarried parents is not perfect (it allows for the violation of the father and mother's equality principle and leads to some problems in law enforcement practice), we consider it necessary to introduce a new procedure into the RF Family Code.

We also propose prohibition of voluntary establishment of paternity, when a person who knows for sure that he is not the father of the child applies to the civil act registration offices. In such cases, acquisition of parental rights should be performed through adoption. The court procedure of adoption will allow for avoiding cases when parental rights are granted

\footnotetext{
${ }^{1}$ On Protecting the Human Rights and Fundamental Freedoms: Convention of 1950. RF Collection of laws. 2001. No. 2. Art. 163.
}

in contradiction with the children's interests. The regulation proposed will be the legal basis for declaring the paternity establishment act invalid in the case it was registered contradictory to the child's interests (e. g., when the applicant informed that he considers himself to be the father of the child).

In our opinion, Russian family legislation should also be amended with a regulation on fictitious paternity establishment with no purpose of the child's upbringing and maintaining. The juridical consequences should be settled for this case, there should be a possibility to compensate for the child's moral damage and to apply the proposed norms on the liability of the guilty person.

The relations resulting from the use of assisted reproductive technologies were defined by us as a special sphere for the legislative changes. We formulated specific issues of paternity establishment that require legal solution, and proposed our recommendations.

It appears that legal regulations forming careful and responsible attitude of men towards getting parental rights can serve as the first stage in overcoming the family and family values crisis of today's society.

\section{References}

1. Aslanov Kh. G. Obespechenie interesov ottsa v roditel'skikh pravootnosheniyakh po semeynomu zakonodatel'stvu Rossiyskoy Federatsii: avtoref. dis ... kand. yurid. nauk [Ensuring the Father's Interests in Parental Legal Relationships under the Family Legislation of the Russian Federation: Synopsis of Cand. jurid. sci.diss.]. Moscow, 2009. 29 p. (In Russ.).

2. Butaev M. V. Problema ottsovstva v sotsial'noy filosofii: avtoref. dis ... kand. filosof. nauk [The Paternity Problem in Social Philosophy: Synopsis of Cand. jurid. sci. diss.]. Saratov, 2013. 18 p. (In Russ.).

3. Gavrilyuk E. D. K voprosu o tselesoobraznosti prinuditel'nogo ustanovleniya ottsovstva; otv. red. O. N. Nizamieva [On the Question of the Advisability of the Compulsory Establishment of Paternity; ed. by O. N. Nizamieva]. Semeynoe pravo na rubezhe $X X-X X I$ vekov: $k$ 20letiyu Konvencii OON o pravakh rebenka: materialy Mezhdunar. nauch.-prakt. konf., 18 dek. 2010 g. - Family Law at the Turn of the $20^{\text {th }}-$ $21^{\text {st }}$ centuries: to the $20^{\text {th }}$ anniversary of the United Nations Convention on the Rights of the Child. Proceedings of the International scientific and practical conference, December 18, 2010. Moscow. 2011. Pp. 20-23. (In Russ.). 
4. Mareeva N.S. Sotsial'naya transformatsiya otnosheniy ottsa i syna $v$ evropeyskoy istorii: dis. ... kand. filosof. nauk [The Social Transformation of the Father-Son Relationship in European History: Cand. philos. sci. diss.]. Moscow, 2010. 23 p. (In Russ.).

5. Matveeva N. A. Prezumptsiya ottsovstva i problemy ee oproverzheniya [Presumption of Paternity and Problems of its Rebuttal]. Semeynoe $i$ zhilishchnoe pravo - Family and Housing Law. 2014. Issue 4. Pp. 39-41. (In Russ.).

6. Pergament A. I. Pravovoe polozhenie vnebrachnykh detey dolzhno byt' izmeneno [The Legal Status of Children Born Out of Wedlock Should Be Changed]. Sovetskoe gosudarstvo i pravo - Soviet State and Law. 1956. Issue 9. Pp. 65-72. (In Russ.).

7. Polyanina A.K. Fakt beremennosti kak osnovanie vozniknoveniya roditel'skikh obyazannostey [The Fact of Pregnancy as a Ground for Parental Duties Incurrence]. Semeynoe $i$ zhilishchnoe pravo - Family and Housing Law. 2012. Issue 1. Pp. 9-11. (In Russ.).

8. Rabets A. M. Pravo rebenka na vyzhivanie $i$ zdorovoe razvitie $i$ ego realizatsiya $v$ zakonodatel'stve Rossiyskoy Federatsii [The Child's Right to Survival and Development, and its Implementation in the Law of the Russian Federation; ed. by O. N. Nizamieva]. Semeynoe pravo na rubezhe $X X-X X I$ vekov: $k$ 20-letiyu Konvencii OON o pravakh rebenka: materialy Mezhdunar. nauch.-prakt. konf., 18 dek. 2010 g. - Family Law at the Turn of the $20^{\text {th }}-21^{\text {st }}$ centuries: to the $20^{\text {th }}$ anniversary of the United Nations Convention on the Rights of the Child. Proceedings of the International scientific and practical conference, December 18, 2010. Moscow, 2011. Pp. 221-229. (In Russ.).

9. Svitnev K. N. Pravovye $i$ eticheskie aspekty posmertnoy reproduktsii [Legal and Ethical Aspects of Posthumous Reproduction]. Pravovye voprosy $v$ zdravookhranenii - Legal Issues in Healthcare. 2011. Issue 6. Pp 30-43. (In Russ.).

10. Stebleva E. V. Problemy realizatsii prav uchastnikov otnosheniy surrogatnogo materinstva: avtoref. dis. ... kand. yurid. nauk [Problems of realization of the rights of participants of surrogate motherhood relations: Synopsis of Cand. jurid. sci. diss.]. Moscow, 2012. 18 p. (In Russ.).

11. Petrazhitskiy L. I. Teoriya prava i gosudarstva $v$ svyazi s teoriey nravstvennosti: $v 2 t$. [Theory of Law and State in Connection with the Theory of Morality: in 2 vols.]. St. Petersburg, 1909. Vol. 1.768 p. (In Russ.).

12. Barnes B. Does «Sperm Donor» Mean «Dad»? ST1 New York Times. 2014. May 2. Available at: http://www.nytimes.com/2014/05/04/fashion/ Jason-Patric-Does-Sperm-Donor-Mean-Dad-parental-rights.html?_r=1 (accessed 08.10.2016). (In Eng.).

13. Conway H. The Law and the Dead. Routledge. New York, 2016. 261 p. (In Eng.).

14. Detrick S. A Commentary on the United Nations Convention on the Rights of the Child. Martinus Nijhoff Publishers Hague, 1999. 790 p. (In Eng.).

15. Hough A., Bingham J. Sperm Donors Can Seek More Parental Rights. The Telegraph. 2013. Feb. 01. Available at: http://www.telegraph.co. uk/news/uknews/law-and-order/9841207/Sperm -donors-can-seek-more-parental-rights.html (accessed 08.10.2016). (In Eng.).

16. Jung M. Bundesverfassungsgericht: Vaterschaftstest Kann nur Innerhalb der Familie Erzwungen Warden. Available at: http://www. vaterschaftsanalyse.de/de/info/aktuelles/bundesverfassungsgericht-vaterschaftstest-kannnur-innerhalb-der-familie-erzwungen-werden/ (accessed 08.10.2016). (In Ger.).

17. Kindregan Ch. P., McBrien M. Assisted Reproductive Technology: A Lawyer's Guide to Emerging Law and Science. American Bar Association, 2006. 336 p. (In Eng.).

18. Pauli E. E. Der Sogenannte Biologische Vater: Ein Vergleich der Französischen Und Deutschen Rechtsentwicklung. Rechtsvergleichung und Rechtsvereinheitlichung 35. 2016. XXI. 189 p. (In Eng.).

19. Rothman C.M. A Method for Obtaining Viable Sperm in the Postmortem State. Fertility and Sterility. Vol. 34. Issue 5. Nov. 1980. P. 512. (In Eng.).

20. Spielman B. Posthumous Reproduction: Ethical and Legal Perspectives. Ethical Dilemmas in Assisted Reproductive Technologies; ed. by Joseph G. Berlin/Boston, 2011. Pp. 289-296. (In Eng.).

21. Strong C., Gingrich J. R., Kutteh W. H. Ethics of Postmortem Sperm Retrieval: Ethics of Sperm Retrieval after Death or Persistent Vegetative State. Human Reproduction. 2000. Apr. 15(4). Pp. 739-745. (In Eng.).

22. Süß B. Die Feststellung der Vaterschaft unabhängig von Anfechtungsverfahren: das Neue Abstammungsrect unter besonderer Berücksichtung der Perspektive der Väter. Peter Lang, Frankfurt am Mein, 2010. 166 p. (In Ger.).

23. Velte G. Die Postmortale Befruchtung im Deutschen und Spanischen Recht. SpringerVerlag. Berlin Heidelberg, 2015. 303 p. DOI 10.1007/978-3-662-44554-9. (In Ger.). 


\section{References in Russian}

1. Асланов Х. Г. Обеспечение интересов отца в родительских правоотношениях по семейному законодательству Российской Федерации: автореф. дисс ... канд. юрид. наук. М., 2009. $29 \mathrm{c}$.

2. Бутаев М. В. Проблема отцовства в социальной философии: автореф. дисс ... канд. филос. наук. Саратов, 2013. 18 с.

3. Гаврилюк Е. Д. К вопросу о целесообразности принудительного установления отцовства // Семейное право на рубеже $\mathrm{XX}$ XXI веков: к 20-летию Конвенции ООН о правах ребенка: материалы Междунар. науч.практ. конф. (г. Казань, Казан. (Приволжский) федер. ун-т, 18 дек. 2010 г.) / отв. ред. О. Н. Низамиева. М.: Статут, 2011. С. 20-23.

4. Мареева Н. С. Социальная трансформация отношений отца и сына в европейской истории: дис. ... канд. филос. наук. М., 2010. 23 с.

5. Матвеева Н. А. Презумпция отцовства и проблемы ее опровержения // Семейное и жилищное право. 2014. № 4. С. 39-41.

6. Пергамент А. И. Правовое положение внебрачных детей должно быть изменено // Coветское государство и право. 1956. № 9. C. 65-72.

7. Полянина А. К. Факт беременности как основание возникновения родительских обязанностей // Семейное и жилищное право. 2012. № 1. C. 9-11.

8. Рабеи А. М. Право ребенка на выживание и здоровое развитие и его реализация в законодательстве Российской Федерации // Cемейное право на рубеже XX-XI веков: к 20-летию Конвенции ООН о правах ребенка: материалы Междунар. науч.-практ. конф. (г. Казань, Казан. (Приволжский) федер. ун-т, 18 дек. 2010 г.) / отв. ред. О. Н. Низамиева. М.: Статут, 2011. С. 221-229.

9. Свитнев К.Н. Правовые и этические аспекты посмертной репродукции // Правовые вопросы в здравоохранении. 2011. № 6 С. 30-43.

10. Стеблева E. B. Проблема реализация прав участников отношений суррогатного материнства: автореф. дис. ... канд. юрид наук. M., 2012. $18 \mathrm{c}$.

11. Петражииякий Л. И. Теория права и государства в связи с теорией нравственности: в 2 т. СПб., 1909. Т. 1.768 с.

12. Barnes B. Does «Sperm Donor» Mean «Dad»? // ST1 New York Times. 2014. May 2. URL: http://www.nytimes.com/2014/05/04/fashion/
Jason-Patric-Does-Sperm-Donor-Mean-Dad-parental-rights.html?_r=1 (дата обращения: 08.10.2016).

13. Conway H. The Law and the Dead. Routledge; New York, 2016. 261 p.

14. Detrick $S$. A Commentary on the United Nations Convention on the Rights of the Child // Martinus Nijhoff Publishers Hague, 1999. $790 \mathrm{p}$.

15. Hough A., Bingham J. Sperm Donors Can Seek More Parental Rights // The Telegraph. 2013. Feb. 01. URL: http://www.telegraph.co.uk/news/ uknews/law-and-order/9841207/Sperm-donorscan-seek-more-parental-rights.html (дата обращения: 08.10.2016).

16. Jung $M$. Bundesverfassungsgericht: Vaterschaftstest Kann nur Innerhalb der Familie Erzwungen Warden. URL: http://www.vaterschaftsanalyse.de/de/info/aktuelles/bundesverfassungsgericht-vaterschaftstest-kann-nur-innerhalb-der-familie-erzwungen-werden/ (дата обращения: 08.10.2016).

17. Kindregan Ch. P., McBrien M. Assisted Reproductive Technology: A Lawyer's Guide to Emerging Law and Science // American Bar Association, 2006. $336 \mathrm{p}$.

18. Pauli E. E. Der Sogenannte Biologische Vater: Ein Vergleich der Französischen Und Deutschen Rechtsentwicklung // Rechtsvergleichung und Rechtsvereinheitlichung 35. 2016. XXI. $189 \mathrm{~S}$.

19. Rothman C. M. A Method for Obtaining Viable Sperm in the Postmortem State // Fertility and Sterility, Nov. 1980. Vol. 34. Iss. 5. P. 512.

20. Spielman B. Posthumous Reproduction: Ethical and Legal Perspectives // Ethical Dilemmas in Assisted Reproductive Technologies / ed. by G. Joseph Berlin; Boston, 2011. Pp. 289-296.

21. Strong C., Gingrich J. R., Kutteh W. H. Ethics of Postmortem Sperm Retrieval: Ethics of Sperm Retrieval after Death or Persistent Vegetative State // Human Reproduction. 2000. Apr. 15(4). Pp. 739-745.

22. Süß B. Die Feststellung der Vaterschaft unabhängig von Anfechtungsverfahren: das Neue Abstammungsrect unter besonderer Berücksichtung der Perspektive der Väter. Peter Lang, Frankfurt am Mein, 2010. $166 \mathrm{~S}$.

23. Velte G. Die Postmortale Befruchtung im Deutschen und Spanischen Recht. SpringerVerlag. Berlin Heidelberg, 2015. 303 S. DOI 10.1007/978-3-662-44554-9. 